\title{
E-Filing, Kualitas Pelayanan, Sanksi Perpajakan dan Kepatuhan Wajib Pajak Orang Pribadi
}

\author{
Ni Luh Putu Rika Yuniasih 1 \\ Fakultas Ekonomi dan Bisnis \\ Universitas Udayana, Indonesia
}

\author{
I Ketut Jati ${ }^{2}$ \\ Fakultas Ekonomi dan Bisnis \\ Universitas Udayana, Indonesia
}

\begin{abstract}
Surel: rikay1099@gmail.com
\section{ABSTRAK}

Salah satu metode efektif dan berpotensi besar dalam meningkatkan kepatuhan wajib pajak adalah dengan reformasi perpajakan. Tujuan penelitian ini untuk mengetahui pengaruh penerapan e-filing, kualitas pelayanan pajak, dan sanksi pajak terhadap tingkat kepatuhan wajib pajak orang pribadi. Populasi penelitian ini adalah wajib pajak orang pribadi yang terdaftar di Kantor Pelayanan Pajak (KPP) Pratama Denpasar Timur yang berjumlah 108.902 Orang. Teknik pengambilan sampel yang digunakan yaitu sampling insidental yang mengambil 100 sampel. Pengumpulan data dilakukan melalui penyebaran kuesioner. Metode analisis yang digunakan adalah Partial Least Square (PLS) Path Modeling dengan alat analisis SmartPLS 3.0. Hasil penelitian ini menunjukkan bahwa semakin tinggi tingkat penggunaan dalam penerapan e-filing, semakin tinggi tingkat kualitas pelayanan pajak, dan semakin tegas dan adil dalam penerapan sanksi perpajakan maka semakin tinggi pula tingkat kepatuhan wajib pajak orang pribadi.
\end{abstract}

Kata Kunci: E-Filing; Kualitas Pelayanan; Sanksi Perpajakan; Kepatuhan Wajib Pajak Orang Pribadi.

\section{E-Filing, Service Quality, Tax Sanctions and Individual Taxpayer Compliance}

\begin{abstract}
One of the effective methods and has great potential in increasing taxpayer compliance is tax reform. The purpose of this study was to determine the effect of the implementation of e-filing, the quality of tax services, and tax sanctions on the level of compliance of individual taxpayers. The population of this study is an individual taxpayer registered at the Tax Service Office (KPP) Pratama Denpasar Timur, amounting to 108,902 people. The sampling technique used is incidental sampling which takes 100 samples. Data was collected through the distribution of questionnaires. The analytical method used is Partial Least Square (PLS) Path Modeling with SmartPLS 3.0 analysis tool. The results of this study indicate that the higher the level of use in the application of e-filing, the higher the level of quality of tax services, and the more firm and fair in the application of tax sanctions, the higher the level of compliance of individual taxpayers.
\end{abstract}

Keywords: E-Filing; Service quality; Tax Sanctions; Individual Taxpayer Compliance.

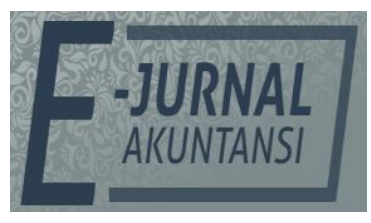

e-ISSN 2302-8556

Vol. 31 No. 12

Denpasar, Desember 2021

Hal. 2988-2999

DOI:

10.24843/EJA.2021.v31.i12.p04

PENGUTIPAN:

Yuniasih, N. L. P. R. \& Jati, I. K. (2021). E-Filing, Kualitas

Pelayanan, Sanksi Perpajakan dan Kepatuhan Wajib Pajak Orang Pribadi. E-Jurnal Akuntansi, 31(12), 2988-2999

RIWAYAT ARTIKEL: Artikel Masuk: 21 Juli 2021 Artikel Diterima: 30 Agustus 2021

Artikel dapat diakses : https://ojs.unud.ac.id/index.php/Akuntansi/index 


\section{PENDAHULUAN}

Indonesia merupakan negara berkembang yang mempunyai berbagai kekayaan sumber daya yang berlimpah dan memiliki potensi yang baik untuk menjadikannya sebagai negara maju. Tetapi saat ini Indonesia belum mampu memaksimalkan sumber daya dan potensi yang ada untuk kemakmuran penduduk Indonesia. Dalam pembangunan nasional perlu pembiayaan pembangunan baik dalam negeri maupun luar negeri (Amran, 2018). Banyak aspek yang membuat Indonesia semakin terpuruk jika dibandingkan dengan negara lainnya. Aspek yang utama adalah ekonomi. Melalui kewajibannya membayar pajak, warga negara telah memberikan bantuan yang merupakan kontribusi penerimaan yang sangat besar dalam Anggaran Pendapatan dan Belanja Negara (APBN) (Indriyani \& Askandar, 2018).

Rendahnya tingkat kepatuhan membayar pajak menjadi salah satu penyebab belum optimalnya penerimaan pajak di Indonesia. Apabila kepatuhan wajib pajak bisa terpenuhi pada suatu negara, maka penerimaan pajak ke kas negara akan semakin meningkat (Hidayati et al., 2017). Kepatuhan akan tercipta jika ada sebuah faktor yang mempengaruhinya, dari sisi pelayanan yang diberikan oleh fiskus, adanya kepastian hukum yang kuat, serta kesadaran masyarakat sendiri sebagai masyarakat yang baik harus melaksanakan kewajibannya. Salah satu faktor yang menyebabkan rendahnya kepatuhan pajak adalah para pegawai yang berada di kantor pajak seringkali tidak memberikan pelayanan secara maksimal (Indriyani \& Askandar, 2018).

Salah satu upaya pemerintah yang dilakukan oleh Dirjen Pajak adalah dengan menerbitkan Keputusan Dirjen Pajak No. Kep-88/PJ/2004 yang dikeluarkan pada 21 Mei 2004 secara resmi meluncurkan suatu produk yakni $e$ filing atau Electronic Filing System. Tujuan atas adanya sistem e-filing yaitu sebagai langkah modernisasi untuk memberikan kualitas pelayanan yang baik dan mudah kepada wajib pajak. E-Filing merupakan suatu sistem elektronik yang digunakan untuk menyampaikan surat pemberitahuan (SPT) dengan memanfaatkan sistem online dan real time serta melaui sebuah penyedia jasa aplikasi yang sudah bekerja sama dengan Direktorat Jendral Pajak (Novi Endaryanti, 2017).

Hal ini sejalan dengan penelitian yang dilakukan Arisandy (2017) menyimpulkan kualitas sistem berpengaruh signifikan terhadap kepatuhan pelaporan SPT Tahunan. Namun penelitian yang dilakukan oleh Gwaro et al. (2016) memperoleh kesimpulan yang bertolak belakang yaitu stabilitas sistem pajak tidak berpengaruh signifikan terhadap kepatuhan perpajakan. Modernisasi perpajakan melalui e-filing merupakan suatu inovasi yang mengacu pada pengembangan teknologi infromasi yang tersedia untuk melaporkan dan mengirimSPT tahunan dapat dilakukan dengan mudah dan efisien karena adanya formulir elektronik yang teredia dalam sistem layanan pajak yang siap untuk digunakan oleh para pengguna layanan SPT sehingga pelaporan SPT dapat dilakukan kapan saja yang diinginkan oleh wajib pajak (Ayu \& Sari, 2017).

Wajib pajak yang memahami hukum perpajakan dengan baik akan berupaya untuk mematuhi segala pembayaran pajak dibandingkan melanggar karena akan merugikannya secara materiil. Apabila wajib pajak tidak mematuhi peraturan perpajakan akan mendapatkan sanksi administrasi seperti denda, bunga, atau pengenaan tarif pajak yang lebih tinggi dan sanksi pidana. Kepatuhan 
wajib pajak juga dipengaruhi oleh sanksi perpajakan Sanksi pajak sebagai pencegah yang efektif untuk mengendalikan perilaku dari wajib pajak (Taing \& Chang, 2021). Menurut Nurbiyansari \& Handayani (2021) meskipun adanya sanksi, masih banyak wajib pajak yang tidak patuh dalam membayar kewajiban perpajakannya. Pentingnya peninjauan kembali terkait dengan pembuatan sanksi perpajakan agar tidak terjadi penghindaran pajak oleh wajib pajak. Hasil tersebut sejalan dengan penelitian Pranata \& Setiawan (2015) bahwa sanksi pajak berpengaruh secara signifikan. Namun, hasil yang berbeda ditemukan oleh penelitian Dicriyani \& Ketut (2016) didapatkan hasil bahwa peran sanksi pajak tidak berpengaruh terhadap kepatuhan wajib pajak. Dalam beberapa tahun terakhir, target pajak tidak tercapai salah satunya karena masih rendahnya tingkat kepatuhan Wajib Pajak.

Topik penelitian akan dijelaskan dan dihubungkan menggunakan kerangka konseptual sebagai berikut.

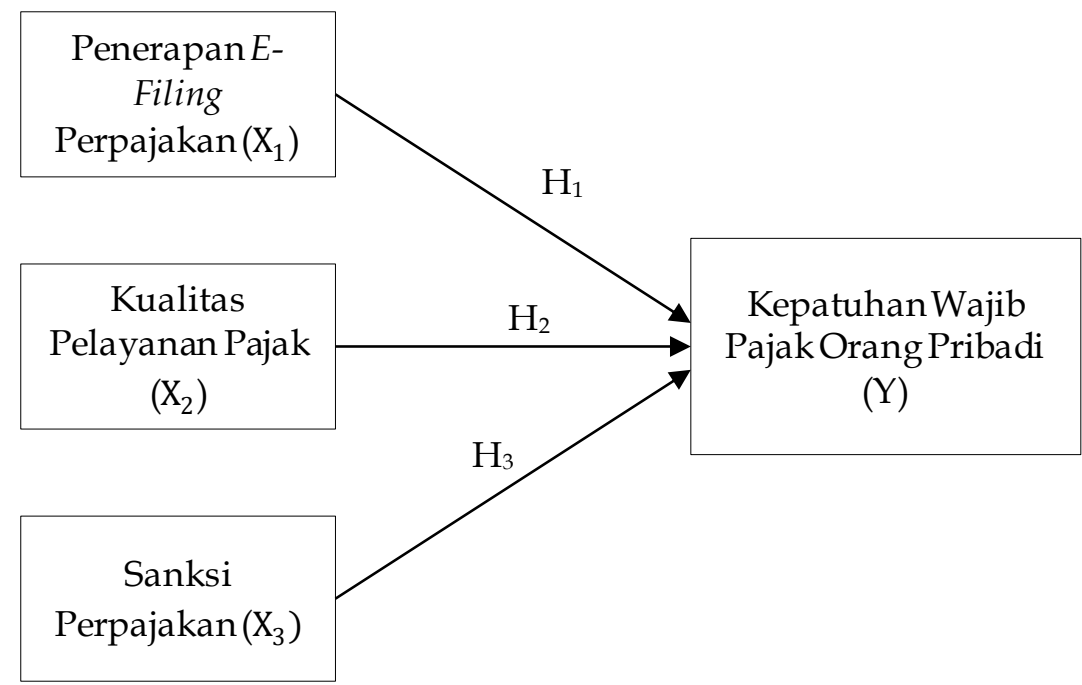

Gambar 1. Model Penelitian

Sumber: Data Penelitian, 2021

Penelitian ini menggunakan teori atribusi dikaji oleh Heider (1958) dan Teori Technology Acceptance Model (TAM) dikembangkan oleh Davis (1989). Teori atribusi memaparkan bahwa terdapat dua faktor dasar yang dapat mempengaruhi perilaku individu yaitu faktor internal dan faktor eksternal. Sedangkan, TAM disusun berdasarkan oleh dua teori dasar mengenai penerimaan teknologi yang telah dikembangkan sebelumnya yaitu Theory of Reasoned Action (TRA) dan Theory of Planned Behavior (TPB). Technology Acceptance Model (TAM) merupakan salah satu teori yang dianggap sangat berpengaruh dalam penggunaan sistem teknologi informasi untuk menjelaskan penerimaan individual terhadap penggunaan sistem teknologi informasi.

Berdasarkan Technology Acceptance Model (TAM), penerapan e-filing merupakan bagian dari modernisasi yang merupakan suatu model yang digunakan untuk menganalisis dan memahami faktor-faktor yang mempengaruhi diterimanya teknologi komputer. Penggunaan sistem $e$-filing dapat memberikan kenyamanan, kemudahan dan kepuasan bagi wajib pajak 
maka kepatuhan akan semakin meningkat, dengan adanya kemudahan dari penggunaan e-filing dan wajib pajak merasa puas dan nyaman, maka akan membuat WPOP semakin patuh dalam melaporkan pajaknya. Berdasarkan penelitian yang dilakukan oleh Kania et al (2017) e-filing berpengaruh positif terhadap kepatuhan wajib pajak. Hal ini serupa dengan penelitian yang dilakukan oleh Lado \& Budiantara (2018) dan Lubis \& Hidayat (2019).

$\mathrm{H}_{1}$ : E-Filing Berpengaruh Positif Pada Kepatuhan Wajib Pajak Orang Pribadi.

Berdasarkan teori atribusi, menjelaskan terkait penyebab perilaku seseorang yang akan ditentukan apakah dari faktor internal atau dari faktor eksternal. Kualitas pelayanan perpajakan merupakan faktor eksternal yang dapatmemengaruhi tingkat kepatuhan wajib pajak. Pelayanan yang baik dari instansi pajak dapat menjadi modal utama untuk menarik perhatian para Wajib Pajak. Para wajib pajak akan patuh dalam memenuhi kewajiban perpajakannya tergantung bagaimana petugas pajak memberikan mutu pelayanan terbaik kepada wajib pajaknya. Penelitian sebelumnya yang dilakukan oleh (Wijayani, 2019) mendapatkan hasil bahwa kualitas pelayanan pajak berpengaruh positif terhadap kepatuhan wajib pajak orang pribadi.

$\mathrm{H}_{2}$ : Kualitas Pelayanan Berpengaruh Positif Pada Kepatuhan Wajib Pajak Orang Pribadi.

Berdasarkan teori atribusi, menjelaskan terkait penyebab perilaku seseorang yang akan ditentukan apakah dari faktor internal atau dari faktor eksternal. Sanksi pajak merupakan faktor eksternal yang dapat memaksa wajib pajak untuk patuh dan taat dengan aturan atau undang-undang yang berlaku dengan kata lain sanksi perpajakan merupakan alat pencegah yang efektif agar WPOP tidak melanggar norma perpajakan. Sanksi pajak merupakan alat pencegah (preventif) agar Wajib Pajak tidak melanggar norma perpajakan (Tene et al., 2017). Sanksi perpajakan dikenakan kepada para wajib pajak yang tidak mematuhi aturan dalam Undang-Undang Perpajakan, agar peraturan perpajakan dipatuhi maka harus ada sanksi perpajakan bagi para pelanggarnya (Dewi et al., 2019). Hasil penelitian (Tene et al., 2017) mengungkapkan bahwa sanksi perpajakan yang dilaksanakan secara tegas berpengaruh positif terhadap kepatuhan pelaporan wajib pajak.

$\mathrm{H}_{3}$ : Sanksi Pajak Berpengaruh Positif Pada Kepatuhan Wajib Pajak Orang Pribadi.

\section{METODE PENELITIAN}

Penelitian ini menggunakan pendekatan kuantitatif yang berbentuk asosiatif kausal, yaitu pendekatan yang bertujuan untuk mengetahui hubungan dan pengaruh antara dua variabel atau lebih yang bersifat sebab akibat (Sugiyono, 2019:16). Tujuan penelitian ini untuk mengetahui bagaimana pengaruh penerapan e-filing perpajakan, kualitas pelayanan, dan sanksi perpajakan pada kepatuhan wajib pajak orang pribadi. Lokasi penelitian dalam penelitian ini adalah di KPP Pratama Denpasar Timur yang terletak di Jalan Tantular No. 4 Dangin Puri Klod, Denpasar Timur, Kota Denpasar, Bali.

Objek dalam penelitian ini adalah sistem e-filing perpajakan, kualitas pelayanan perpajakan, sanksi perpajakan, dan kepatuhan wajib pajak orang pribadi. Penelitian ini terdiri dari variabel terikat yaitu Kepatuhan Wajib Pajak 
Orang Pribadi $(\mathrm{Y})$ dan variabel bebas yaitu e-filing Perpajakan $\left(\mathrm{X}_{1}\right)$, Kualitas Pelayanan $\left(X_{2}\right)$, dan Sanksi Perpajakan $\left(X_{3}\right)$.

E-Filing adalah suatu cara penyampaian SPT elektronik yang dilakukan secara online dan real time melalui internet di website Direktorat Jenderal Pajak (http://www.pajak.go.id) atau Penyedia Layanan SPT Elektronik atau Application Service Provider (ASP). Variabel ini diukur dengan mengadopsi kuesioner yang mengacu pada penelitian Prasetyo \& Idayati (2019) yang terdiri dari 7 pernyataan, indikator pengukuran yang digunakan yaitu: kemudahan penggunanaan sistem perpajakan, kemudahan dalam mempelajari, realisasi dari kebutuhan pemakai, efektifitas sistem perpajakan, akurasi sistem perpajakan, isi basis data tentang perpajakan dan kebermanfaatan sistem perpajakan.

Kualitas pelayanan pajak dapat diartikan sebagai kegiatan pelayanan yang dilakukan oleh petugas pajak (fiskus) untuk membantu, membimbing, atau menyiapkan segala sesuatu yang diperlukan atau dibutuhkan wajib pajak dalam memenuhi kewajibannya membayar pajak. Indikator pengukuran variabel kualitas pelayanan yang digunakan dalam penelitian ini diadopsi dari hasil pengembangan dari Bahri et al (2019) yaitu keandalan petugas pajak, ketanggapan, empati, manfaat petugas pajak, efektifitas, jaminan, dan bukti langsung.

Sanksi pajak digunakan oleh aparatur pajak (fiskus) untuk mencegah adanya kecurangan yang dilakukan wajib pajak dalam memenuhi kewajibannya membayar pajak. Indikator pengukuran variabel sanksi perpajakan yang digunakan dalam penelitian ini diadopsi dari penelitian Pranata \& Setiawan (2015) yaitu sanksi perpajakan, sanksi perpajakan yang dikenakan bagi pelanggar aturan pajak cukup berat, pengenaan sanksi pajak yang cukup berat merupakan salah satu sarana untuk mendidik wajib pajak, sanksi pajak harus dikenakan kepada pelanggarnya tanpa toleransi, dan realisasi dari kebutuhan pemakai.

Wajib pajak dikatakan patuh jika mereka dapat memenuhi kewajiban pajak serta melaksanakan hak dalam bidang perpajakan. Indikator pengukuran variabel kepatuhan wajib pajak yang digunakan dalam penelitian ini diadopsi dari penelitian Arisandy (2017) yaitu mendaftar NPWP, realisasi dari wajib pajak, menghitung pajak terutang, melaporkan SPT, isi basis data wajib pajak dan membayar kewajiban pajak.

Populasi dalam penelitian ini adalah seluruh wajib pajak orang pribadi yang tercatat di KPP Pratama Denpasar Timur. Jumlah populasi dalam penelitian ini yaitu 108.902 wajib pajak orang pribadi. Teknik pengambilan sampel yang digunakan dalam penelitian ini adalah sampling insidental. Sampel memiliki karakteristik yaitu, memiliki NPWP, melek teknologi, pendidikan minimal SMA, dan usia tidak lebih dari 60 tahun. Metode yang digunakan untuk menentukan jumlah sampel adalah menggunakan rumus Slovin, sebagai berikut.

$$
\mathrm{n}=\mathrm{N} /(1+\mathrm{N} \mathcal{E} 2)
$$

Keterangan:

$$
\begin{array}{ll}
\mathrm{n} & =\text { jumlah sampel } \\
\mathrm{N} & =\text { jumlah populasi } \\
\mathcal{E} & =\text { jumlah toleransi kesalahan (error tolerance) }
\end{array}
$$

Penelitian ini mengambil toleransi kesalahan sebesar 10\% $(0,1)$, sehingga perhitungan menggunakan rumus Slovin Wajib Pajak Orang Pribadi Karyawan adalah sebagai berikut. 


$$
\mathrm{n}=\mathrm{N} /(1+\mathrm{N} \varepsilon 2)=108.902 /(1+108.902 \times 0,12)=100
$$

Dengan demikian, jumlah sampel yang didapatkan sebanyak 100 sampel. Penelitian ini menggunakan metode pengumpulan data dengan cara menyebarkan kuesioner kepada sampel penelitian yang bersangkutan. Penelitian ini menggunakan Partial Least Square (PLS) untuk menguji instrumen penelitian. PLS merupakan model persamaan Structural Equation Modeling (SEM) yang berbasis komponen atau varian. Teknik analisis data yang digunakan dalam penelitian ini berupa teknik analisis statistik deskriptif. Pengujian hipotesis dalam penelitian ini menggunakan teknik analisis statistik inferensial dengan metode analisis Structural Equation Modeling (SEM) berbasis Partial Least Square (PLS). Sebagai alternatif convariance based SEM, pendekatan variance based atau component based dengan PLS orientasi bergeser dari menguji model kausalitas atau teori ke component based predictive model (Ermawati, 2018).

\section{HASIL DAN PEMBAHASAN}

Responden yang digunakan dalam penelitian ini adalah Wajib Pajak orang pribadi yang terdaftar di KPP Pratama Denpasar Timur. Peneliti berhasil mengumpulkan data melalui kuesioner yang dibagikan sebanyak 100 buah kuesioner. Responden yang terdapat pada KPP Pratama Denpasar Timur memiliki karakter atau identitas yang berbeda dalam melakukan pengisian kuesioner.

\section{Tabel 1. Karakteristik Responden}

\begin{tabular}{clcc}
\hline No & \multicolumn{1}{c}{ Karakteristik Responden } & Frekuensi & Jumlah Presentase $(\%)$ \\
\hline 1 & Berdasarkan Jenis Kelamin & 60 & 60 \\
& Laki-laki & 40 & 40 \\
& Perempuan & 100 & 100 \\
& Jumlah & & \\
2 & Berdasarkan Usia & 30 & 30 \\
& 25-35 Tahun & 35 & 35 \\
& 36-45 Tahun & 33 & 33 \\
& 46-55 Tahun & 2 & 2 \\
& >56 Tahun & 100 & 100 \\
& Jumlah & & \\
3 & Berdasarkan Pendidikan Terakhir & 45 & 45 \\
& SMA & 15 & 15 \\
& DIPLOMA & 40 & 40 \\
& S1 & 100 & 100 \\
& Jumlah & & 100 \\
Berdasarkan Kepemilikan NPWP & 100 & 0 \\
& Ya & 0 & 100 \\
& Tidak & 100 & 15 \\
& Jumlah & & 30 \\
Berdasarkan Jenis Pekerjaan & 15 & 35 \\
& PNS & 30 & 20 \\
& Karyawan swasta & 35 & 100 \\
& Wirausaha & 20 & \\
& Lainnya & 100 & \\
& Jumlah & & \\
& & &
\end{tabular}

Sumber: Data Penelitian, 2021 
Berdasarkan Tabel 1, dapat dilihat karakteristik responden yang pertama adalah jenis kelamin, banyaknya responden berjenis kelamin laki-laki sejumlah 60 orang dan responden berjenis kelamin perempuan sejumlah 40 orang. Karakteristik kedua yaitu usia, banyaknya responden berusia 25-35 tahun sejumlah 30 orang, banyaknya responden berusia 36-45 tahun sejumlah 35 orang, banyaknya responden berusia 46-55 tahun sejumlah 33 orang, banyaknya responden berusia $>56$ tahun sejumlah 2 orang. Karakteristik ketiga responden dibedakan berdasarkan tingkat pendidikan dapat dilihat bahwa responden dengan pendidikan terakhir SMA sejumlah 45 orang, Diploma sejumlah 15 orang, S1 sejumlah 40 orang. Karakteristik keempat yaitu berdasarkan kepemilikan NPWP dapat dibedakan menjadi responden yang memiliki NPWP sejumlah 100 orang dan yang tidak memiliki NPWP sejumlah 0 orang. Karakteristik responden kelima dapat dibedakan berdasakan jenis pekerjaan tersebut dapat dilihat bahwa banyaknya responden sebagai PNS sejumlah 15 orang, banyaknya responden sebagai karyawan swasta sejumlah 30 orang, banyaknya responden sebagai wirausaha sejumlah 35 orang, dan banyaknya responden dengan pekerjaan lainnya sejumlah 20 orang.

Tabel 2. Statistik Deskriptif

\begin{tabular}{lccccc}
\hline \multicolumn{1}{c}{ Variabel } & Mean & Median & Min & Max & $\begin{array}{c}\text { Std } \\
\text { Deviation }\end{array}$ \\
\hline Penerapane-filing perpajakan(X1) & 18,72 & 19 & 12 & 26 & 3,124 \\
Kualitas pelayanan pajak (X2) & 23,40 & 24 & 14 & 28 & 3,250 \\
Sanksi perpajakan(X3) & 13,52 & 13 & 10 & 19 & 2,119 \\
Kepatuhan wajib pajak orang & 18,09 & 18 & 12 & 24 & 2,631 \\
pribadi $(\mathrm{Y})$ & & & & & \\
\hline
\end{tabular}

Sumber: Data Penelitian, 2021

Berdasarkan hasil statistik deskriptif pada Tabel 2, variabel penerapan $e$ filing perpajakan $\left(X_{1}\right)$ memiliki nilai minimum sebesar 12 dan maksimum 26. Adapun rerata untuk variabel ini adalah 18,72 dengan standar deviasi sebesar 3,124 . Variabel Kualitas pelayanan pajak $\left(X_{2}\right)$ memiliki nilai minimum sebesar 14 dan maksimum 28. Adapun rerata untuk variabel ini adalah 23,40 dengan standar deviasi sebesar 3,250. Variabel Sanksi perpajakan $\left(X_{3}\right)$ memiliki nilai minimum sebesar 10 dan maksimum 19. Adapun rerata untuk variabel ini adalah 13,52 dengan standar deviasi sebesar 2,119. Variabel Kepatuhan wajib pajak orang pribadi (Y) memiliki nilai minimum sebesar 12 dan maksimum 24 . Adapun rerata untuk variabel ini adalah 18,09 dengan standar deviasi sebesar 2,631.

Sistem persamaan struktural yang digunakan dalam penelitian ini adalah sebagai berikut.

$$
Y=0,465 X_{1}+0,220 X_{2}+0,208 X_{3}+\mathcal{E}
$$

Keterangan:

$\mathrm{X}_{1} \quad=$ Penerapan $\mathrm{e}$-filing perpajakan

$\mathrm{X}_{2} \quad=$ Kualitas pelayanan pajak

$\mathrm{X}_{3} \quad=$ Sanksi perpajakan

$\mathrm{Y} \quad=$ Kepatuhan wajib pajak orang pribadi

$\mathcal{E} \quad=$ error 
Tabel 3. Nilai Loading Factor untuk Masing-Masing Indikator

\begin{tabular}{|c|c|c|}
\hline Variabel & Indikator & Outer Loading \\
\hline \multirow{7}{*}{ Penerapane-filing perpajakan $\left(X_{1}\right)$} & X.1.1 & 0,756 \\
\hline & X.1.2 & 0,790 \\
\hline & X.1.3 & 0,662 \\
\hline & X.1.4 & 0,830 \\
\hline & X.1.5 & 0,784 \\
\hline & X.1.6 & 0,720 \\
\hline & X.1.7 & 0,802 \\
\hline \multirow{7}{*}{ Kualitas pelayanan pajak $\left(X_{2}\right)$} & $X .2 .1$ & 0,838 \\
\hline & $\mathrm{X} .2 .2$ & 0,852 \\
\hline & $\mathrm{X} .2 .3$ & 0,773 \\
\hline & X.2.4 & 0,835 \\
\hline & X.2.5 & 0,696 \\
\hline & X.2.6 & 0,793 \\
\hline & $\mathrm{X} .2 .7$ & 0,744 \\
\hline \multirow{5}{*}{ Sanksi perpajakan $\left(X_{3}\right)$} & X.3.1 & 0,708 \\
\hline & X.3.2 & 0,712 \\
\hline & X.3.3 & 0,732 \\
\hline & X.3.4 & 0,688 \\
\hline & X.3.5 & 0,773 \\
\hline \multirow{6}{*}{ Kepatuhan wajib pajak orang pribadi $(Y)$} & Y.1 & 0,848 \\
\hline & $Y .2$ & 0,779 \\
\hline & Y.3 & 0,808 \\
\hline & Y.4 & 0,730 \\
\hline & Y.5 & 0,627 \\
\hline & Y.6 & 0,676 \\
\hline
\end{tabular}

Sumber: Data penelitian, 2021

Berdasarkan Tabel 3, dapat dikatakan bahwa seluruh indikator yang digunakan memiliki nilai loading factor diatas 0,50. Nilai ini mengindikasikan bahwa model yang dibentuk sudah cukup baik dan indikator yang digunakan untuk mengukur variabel valid.

Berdasarkan Tabel 4, dapat dilihat bahwa semua variabel yang digunakan (variabel eksogen dan endogen) memiliki nilai $A V E$ lebih besar dari 0,50. Hal ini bahwa keseluruhan variabel yang digunakan valid.

Tabel 4. Nilai AVE Masing-Masing Variabel

\begin{tabular}{lc}
\hline \multicolumn{1}{c}{ Variabel } & Average Variance Extracted(AVE) \\
\hline Kepatuhan wajib pajak orang pribadi $(\mathrm{Y})$ & 0,560 \\
Penerapane-filing perpajakan $\left(\mathrm{X}_{1}\right)$ & 0,585 \\
Kualitas pelayanan pajak $\left(\mathrm{X}_{2}\right)$ & 0,627 \\
Sanksi perpajakan $\left(\mathrm{X}_{3}\right)$ & 0,523 \\
\hline
\end{tabular}

Sumber: Data Penelitian, 2021 
Tabel 5. Uji Reliabilitas

\begin{tabular}{lcc}
\hline \multicolumn{1}{c}{ Variabel } & Cronbach's Alpha & Composite Reliability \\
\hline Kepatuhan wajib pajak orang pribadi $(\mathrm{Y})$ & 0,840 & 0,883 \\
Penerapane-filing perpajakan $\left(\mathrm{X}_{1}\right)$ & 0,881 & 0,908 \\
Kualitas pelayanan pajak $\left(\mathrm{X}_{2}\right)$ & 0,900 & 0,921 \\
Sanksi perpajakan $\left(\mathrm{X}_{3}\right)$ & 0,776 & 0,846 \\
\hline
\end{tabular}

Sumber: Data penelitian, 2021

Berdasarkan Tabel 5, dapat dilihat bahwa masing-masing variabel memiliki nilai cronbach's alpha dan composite reliability yang lebih besar dari 0,70 sehingga dapat dikatakan variabel yang digunakan reliable. Hal ini berarti, variabel ini dapat digunakan secara berulang-ulang pada subjek yang sama atau berbeda untuk mengukur sesuatu dengan hasil yang konsisten.

Tabel 6. Uji Inner Model (Structural Model)

\begin{tabular}{lcc}
\hline & R Square & R Square Adjusted \\
\hline Kepatuhan wajib pajak orang pribadi $(\mathrm{Y})$ & 0,506 & 0,491 \\
\hline
\end{tabular}

Sumber: Data Penelitian, 2021

Berdasarkan Tabel 6, dapat dikatakan bahwa variabel endogen kepatuhan wajib pajak orang pribadi memiliki nilai $R$-Square sebesar 0,506 atau $50,6 \%$. Nilai $50,6 \%$ tersebut memiliki arti bahwa sebesar $50,6 \%$ variabel eksogen yaitu kualitas pelayanan pajak, penerapan e-filing perpajakan dan sanksi perpajakan dapat menjelaskan variabel kepatuhan wajib pajak orang pribadi. Sedangkan sebanyak $49,4 \%$ dijelaskan oleh variabel lain diluar penelitian ini. Berdasarkan nilai tersebut dapat dikatakan bahwa model dalam penelitian ini termasuk dalam moderate $(0,50$ $-0,75)$.

Tabel 7. Uji Hipotesis

\begin{tabular}{|c|c|c|c|}
\hline & $\begin{array}{c}\text { T Statistics } \\
(|O / S T D E V|)\end{array}$ & P Values & Keterangan \\
\hline $\begin{array}{l}\text { Penerapane-filing perpajakan }\left(\mathrm{X}_{1}\right) \text {-> } \\
\text { Kepatuhan wajib pajak orang pribadi }(\mathrm{Y})\end{array}$ & 7,043 & 0,000 & H1 diterima \\
\hline $\begin{array}{l}\text { Kualitas pelayanan pajak }\left(\mathrm{X}_{2}\right)-> \\
\text { Kepatuhan wajib pajak orang pribadi }(\mathrm{Y})\end{array}$ & 2,614 & 0,009 & H2 diterima \\
\hline $\begin{array}{l}\text { Sanksi perpajakan }\left(\mathrm{X}_{3}\right) \text {-> Kepatuhan } \\
\text { wajib pajak orang pribadi }(Y)\end{array}$ & 2,554 & 0,011 & H3 diterima \\
\hline
\end{tabular}

Sumber: Data Penelitian, 2021

Nilai t-statistik menunjukkan nilai 7,043. Nilai ini lebih besar dari nilai ttabel yaitu 1,645 . Nilai $p$-value dari hubungan antar variabel ini adalah 0,000 dan nilai ini lebih kecil dibandingkan dengan tingkat kesalahan/signifikansi 0,05. Berdasarkan data tersebut dapat dikatakan bahwa penerapan e-filing perpajakan berpengaruh positif dan signifikan terhadap kepatuhan wajib pajak orang pribadi di KPP Pratama Denpasar Timur. Hal ini memiliki arti bahwa semakin tinggi tingkat penerapan -filing maka semakin tinggi pula tingkat kepatuhan wajib pajak orang pribadi. Hasil ini mendukung Technology Acceptance Model (TAM) terkait penerapan e-filing merupakan bagian dari modernisasi yang merupakan suatu model yang digunakan untuk menganalisis dan memahami faktor-faktor yang mempengaruhi diterimanya teknologi komputer. Hasil penelitian ini sejalan dengan penelitian yang dilakukan oleh Lado \& Budiantara, 2018 yang 
menyebutkan bahwa sistem e-Filing perpajakan berpengaruh positif terhadap kepatuhan Wajib Pajak Orang Pribadi.

Nilai t-statistik menunjukkan nilai 2,614. Nilai ini lebih besar dari nilai ttabel yaitu 1,645. Nilai $p$-value dari hubungan antar variabel ini adalah 0,009 dan nilai ini lebih kecil dibandingkan dengan tingkat kesalahan/signifikansi 0,05. Berdasarkan data tersebut dapat dikatakan bahwa kualitas pelayanan pajak berpengaruh positif dan signifikan terhadap kepatuhan wajib pajak orang pribadi di KPP Pratama Denpasar Timur. Hal ini memiliki arti bahwa semakin tinggi tingkat kualitas pelayanan pajak maka semakin tinggi pula tingkat kepatuhan wajib pajak orang pribadi. Hasil ini mendukung teori atribusi terkait penerapan kualitas pelayanan perpajakan merupakan faktor eksternal yang dapat memengaruhi tingkat kepatuhan wajib pajak. Hasil penelitian ini sejalan dengan penelitian yang dilakukan oleh Tene et al., 2017 yang menyebutkan bahwa kualitas pelayanan perpajakan berpengaruh positif terhadap kepatuhan Wajib Pajak Orang Pribadi.

Nilai t-statistik menunjukkan nilai 2,554. Nilai ini lebih besar dari nilai ttabel yaitu 1,645. Nilai p-value dari hubungan antar variabel ini adalah 0,011 dan nilai ini lebih kecil dibandingkan dengan tingkat kesalahan/signifikansi 0,05. Berdasarkan data tersebut dapat dikatakan bahwa sanksi perpajakan berpengaruh positif dan signifikan terhadap kepatuhan wajib pajak orang pribadi di KPP Pratama Denpasar Timur. Hal ini memiliki arti bahwa semakin tinggi tingkat sanksi perpajakan maka semakin tinggi pula tingkat kepatuhan wajib pajak orang pribadi. Hasil ini mendukung teori atribusi terkait penerapan sanksi perpajakan merupakan faktor eksternal yang dapat memengaruhi tingkat kepatuhan wajib pajak. Hasil penelitian ini sejalan dengan penelitian yang dilakukan oleh Endaryanti, 2017 yang menyebutkan bahwa sanksi perpajakan berpengaruh positif terhadap kepatuhan Wajib Pajak Orang Pribadi.

\section{SIMPULAN}

Penerapan e-filing perpajakan berpengaruh positif dan signifikan terhadap kepatuhan wajib pajak orang pribadi. Hasil ini menunjukkan bahwa jika penerapan e-filing perpajakan meningkat maka kepatuhan wajib pajak orang pribadi juga meningkat. Kualitas pelayanan pajak berpengaruh positif dan signifikan terhadap kepatuhan wajib pajak orang pribadi. Hal ini berarti, jika kualitas pelayanan pajak meningkat maka kepatuhan wajib pajak orang pribadi juga meningkat. Sanksi perpajakan berpengaruh positif dan signifikan terhadap kepatuhan wajib pajak orang pribadi. Hal ini berarti, jika sanksi perpajakan meningkat maka kepatuhan wajib pajak orang pribadi juga meningkat.

Untuk meningkatkan penyempurnaan dan inovasi berkelanjutan mengenai sistem elektronik perpajakan yang ada sehingga akan lebih memudahkan dalam penggunaan e-filing bagi wajib pajak dalam melaporkan SPT Tahunannya. Hal yang dapat dilakukan adalah dengan meningkatkan kegiatan sosialisasi secara langsung kepada masyarakat terkait dengan sistem perpajakan modern beserta sanksi perpajakan jika wajib pajak lalai dalam melaksanakan kewajiban dalam melaporkan dan membayar pajaknya. Partisipan nantinya akan memperoleh informasi mengenai sistem dan aturan perpajakan dan dapat melakukan konsultasi kepada pihak petugas pajak apabila mempunyai permasalahan dan 
pertanyaan terkait dengan materi yang dijelaskan pada saat sosialisasi berlangsung.

\section{REFERENSI}

Amran, A. (2018). Pengaruh Sanksi Perpajakan, Tingkat Pendapatan dan Kesadaran Wajib Pajak terhadap Kepatuhan Wajib Pajak Orang Pribadi. ATESTASI : Jurnal Ilmiah Akuntansi, 1(1), 1-15.

Arisandy, N. (2017). Pengaruh Pemahaman Wajib Pajak, Kesadaran Wajib Pajak dan Sanksi Pajak Terhadap Kepatuhan Wajib Pajak Orang Pribadi Yang Melakukan Kegiatan Bisnis Online Di Pekanbaru. Jurnal Ilmiah Ekonomi Dan Bisnis, 14(1), 62-71.

Ayu, V., \& Sari, P. (2017). Pengaruh Tax Amnesty ,Pengetahuan Perpajakan, Dan Pelayanan Fiskus Terhadap Kepatuhan Wajib Pajak. Sekolah Tinggi Ilmu Ekonomi Indonesia (STIESIA) Surabaya. 6.

Bahri, S., Diantimala, Y., \& Majid, M. (2019). Pengaruh Kualitas Pelayanan Pajak, Pemahaman Peraturan Perpajakan Serta Sanksi Perpajakan Terhadap Kepatuhan Wajib Pajak (Pada Kantor Pajak Kpp Pratama Kota Banda Aceh). Jurnal Perspektif Ekonomi Darussalam, 4(2), 318-334.

Citra Dewi, R., Pratiwi, H., Rahmamuthi, A., Agus Petra, B., \& Ramadhanu, A. (2019). Pengaruh Sistem E-Billing Dan Kualitas Pelayanan Terhadap Kepatuhan Wajib Pajak. Jurnal Teknologi Dan Sistem Informasi Bisnis, 1(2), 1317.

Dicriyani, N. L. G. M., \& Ketut, B. I. (2016). Pengaruh Kualitas Pelayanan dan Pengetahuan Perpajakan Pada Perilaku Kepatuhan Wajib Pajak Dengan Niat Sebagai Pemoderasi. E-Jurnal Ekonomi Dan Bisnis Universitas Udayana, 10, 3329-3358.

Gwaro, Ondara Thomas, Kimani Maina, and Josphat Kwasira. 2016. "Influence of Online Tax Filing on Tax Compliance among Small and Medium Enterprises in Nakuru Town, Kenya." Journal of Business and Management.

Indriyani, N., \& Askandar, N. S. (2018). Pengaruh kualitas pelayanan, sanksi perpajakan, biaya-biaya kepatuhan pajak dan penerapan e-filing pada kepatuhan wajib pajak (studi kasus di Desa Sengguruh Kecamatan Kepanjen Kabupaten Malang). E-JRA Fakultas Ekonomi Dan Bisnis Universitas Islam Malang, 07(07), 1-13.

Kania, P., Wahyuni, A., Luh, N., Erni, G., \& Arie, M. (2017). Pengaruh Penerapan E-System Perpajakan Terhadap Tingkat Kepatuhan Wajib Pajak Orang Pribadi Dalam Membayar Pajak Pada Kantor Pelayanan Pajak ( Kpp ) Pratama Singaraja. JIMAT (Jurnal Ilmiah Mahasiswa Akuntansi) Undiksha, 7(1).

Lado, Y. O., \& Budiantara, M. (2018). Pengaruh Penerapan Sistem E-Filling Terhadap Kepatuhan Wajib Pajak Orang Pribadi Pegawai Negeri Sipil Dengan Pemahaman Internet Sebagai Variabel Pemoderasi (Studi Kasus pada Dinas Perindustrian dan Perdagangan DIY). Jurnal Riset Akuntansi Mercu Buana, 4(1), 59.

Lubis, H. Z., \& Hidayat, M. A. (2019). Pengaruh Modernisasi Administrasi Perpajakan Terhadap Kepatuhan Wajib Pajak Orang Pribadi Dalam Pelaporan Spt (Studi Empiris Pada Kpp Pratama Medan... Prosiding FRIMA (Festival Riset..., 65-72. 
Novi Endaryanti, R. (2017). Pengaruh Kualitas Pelayanan, Sanksi Perpajakan, Biaya Kepatuhan Pajak, Penerapan E-Filing Dan Pengetahuan Pajak Terhadap Kepatuhan Wajib Pajak (Studi Empiris Pada Kpp Pratama Surakarta). Jurnal Ekonomi Dan Bisnis, 1-15.

Nur, G. A. (2018). Pengaruh Pemahaman Peraturan Perpajakan, Kualitas Pelayanan, Kesadaran Wajib Pajak Dan Sanksi Pajak Terhadap Kepatuhan Wajib Pajak Orang Pribadi. Ekobis Dewantara, 15(40), 6-13.

Nurbiyansari, E., \& Handayani, A. A. (2021). Pengaruh Self Assessment System, Keadilan Pajak, Ketepatan Pengalokasian, Teknologi dan Informasi Perpajakan Terhadap Persepsi Wajib Pajak Orang Pribadi Mengenai Penggelapan Pajak (Tax Evasion) (Studi Kasus Pada Wajib Pajak Orang di Kabupaten Sidoarjo. Liability, 03(1), 77-107.

Pasal 1 Undang-Undang Nomor 28 Tahun 2007 tentang Ketentuan Umum dan Tata Cara Perpajakan.

Pasal 23A Undang-Undang 1945 Pasal 23A tentang pajak dan pungutan lain.

Pasal 37A Undang-Undang Nomor 28 Tahun 2007 tentang Ketentuan Umum dan Tata Cara Perpajakan.

Pranata, P. A., \& Setiawan, P. E. (2015). Pengaruh Sanksi Perpajakan, Kualitas Pelayanan Dan Kewajiban Moral Pada Kepatuhan Wajib Pajak. 2, 456-473.

Prasetyo, A., \& Idayati, F. (2019). Pengaruh E-Filing Terhadap Kepatuhan Wajib Pajak Dengan Pemahaman Internet Dan Sosialisasi Perpajakan Sebagai Pemoderasi. Jurnal Ilmu Dan Riset Akuntansi.... http:/ / jurnalmahasiswa.stiesia.ac.id/index.php/jira/article/view/2731

Rahyuda, I Ketut. 2017. Metode Penelitian Bisnis. Denpasar: Udayana University Press

Sugiyono. 2017. Metode Penelitian Kuantitatif, Kualitatif, Kombinasi Dan R\&D. Bandung: Alfabeta

Taing, H. B., \& Chang, Y. (2021). Determinants of Tax Compliance Intention: Focus on the Theory of Planned Behavior. International Journal of Public Administration, 44(1), 62-73.

Tene, J. H., Sondakh, J. J., \& Warongan, J. D. (2017). Pengaruh Pemahaman Wajib Pajak, Kesadaran Pajak, Sanksi Perpajakan dan Pelayanan Fiskus Terhadap Kepatuhan Wajib Pajak (Studi Empiris Pada Wajib Pajak Orang Pribadi yang Terdaftar di KPP Pratama Manado). Jurnal EMBA, 5(2), 443-453.

Undang-Undang Republik Indonesia Nomor 28 Tahun 2007 tentang Perubahan Ketiga Atas Undang-undang Nomor 6 Tahun 1983 tentang Ketentuan Umum dan Tata Cara Perpajakan.

Wijayani, I. G. A. M. S. (2019). Pengaruh Kualitas Pelayanan, Sanksi Perpajakan, Biaya KepatuhanPajak, dan Penerapan E-Filling pada Kepatuhan Pelaporan Wajib Pajak Orang Pribadi di Kantr Pelayanan Pajak Pratama Denpasar Timur. Jurnal Sains, Akuntansi Dan Manajemen, 1(1), 101-124. 